\title{
Development of a technique to sample and quantify pineapple internal atmosphere
}

\author{
Marc LEBRUN*, Marie-Noelle DUCAMP
}

Cirad-Flhor, TA 50 / PS4

34398 Montpellier Cedex 5, France

marc.lebrun@cirad.fr
${ }^{*}$ Correspondence and reprints

Fruits, 2004, vol. 59, p. 431-435 (C) 2005 Cirad/EDP Sciences All rights reserved

DOI: 10.1051/fruits:2005005

RESUMEN ESPAÑOL, p. 435

\section{Development of a technique to sample and quantify pineapple internal atmosphere.}

Abstract - Introduction. As a living organism, fruit is a site of intense gas exchange due to respiration. Carbon dioxide, oxygen and ethylene are the main components involved in this biological activity; they influence the fruit maturity and ripening phenomena. To help studies on pineapple ripening, this paper presents an easy technique to recover and measure the internal atmosphere of pineapple. Materials methods. Experiments were performed with 30 pineapples (two varieties) at the maturity stage. After a procedure validation with standard gas, the sampling technique was applied to pineapple pieces. The fruit's internal atmosphere was released after scratching the fruit into a calcium chloride-saturated brine. The recovered gas was transferred into an air-tight flask equipped with a septum and a bladder. The headspace was analysed with a gas chromatograph or an IR analyser, at atmospheric pressure. Results. Twenty complete procedure cycles were done with three different standard gases to test the reproducibility of the technique. Each pineapple of each variety was sampled once according to the procedure. All of the results were situated in the best standardisation range for reproducibility. Conclusion. The main advantages and drawbacks of the technique are presented.

France / pineapples / maturation / respiration / gas exchange / measurement / methods

\section{Mise au point d'une technique d'échantillonnage et de mesure de l'atmosphère interne de l'ananas.}

Résumé - Introduction. En tant qu'organisme vivant, le fruit est le siège d'échanges gazeux intenses dus à la respiration. Le gaz carbonique, l'oxygène et l'éthylène sont les principaux composants impliqués dans cette activité biologique; ils influencent la maturité du fruit et les métabolismes de la maturation. Afin de faciliter les études sur le mûrissement de l'ananas, le document présente une technique facile, permettant de récupérer et de doser l'atmosphère interne de l'ananas. Materiel et méthodes. Des expérimentations ont été effectuées sur 30 ananas mûrs (deux variétés). Après une validation du procédé effectuée à l'aide de gaz étalon, la technique mise au point a été appliquée à des demi-ananas. L'atmosphère interne du fruit a été libérée après grattage d'un fruit coupé en deux, dans une saumure saturée en chlorure de calcium. Le gaz récupéré a été transféré dans un flacon étanche sur lequel ont été adaptés une vessie souple et un septum. Le dispositif a permis le dosage à la pression atmosphérique, avec un chromatographe en phase gazeuse ou un analyseur de gaz par infrarouge. Résultats. Pour vérifier la reproductibilité de la technique, vingt cycles complets de la procédure ont été faits avec trois mélanges gazeux de référence différents. Chaque ananas a été échantillonné une fois en appliquant la procédure. Tous les résultats obtenus se sont situés dans la gamme de standardisation. Conclusion. Les avantages et les inconvénients principaux de la technique ont été présentés.

France / Ananas (fruits) / maturation / respiration / échange gazeux / mesure / méthode 
Figure 1.

Sampling flask equipped with a bladder and a septum, used to recover the internal atmosphere released by the respiration of a pineapple piece.

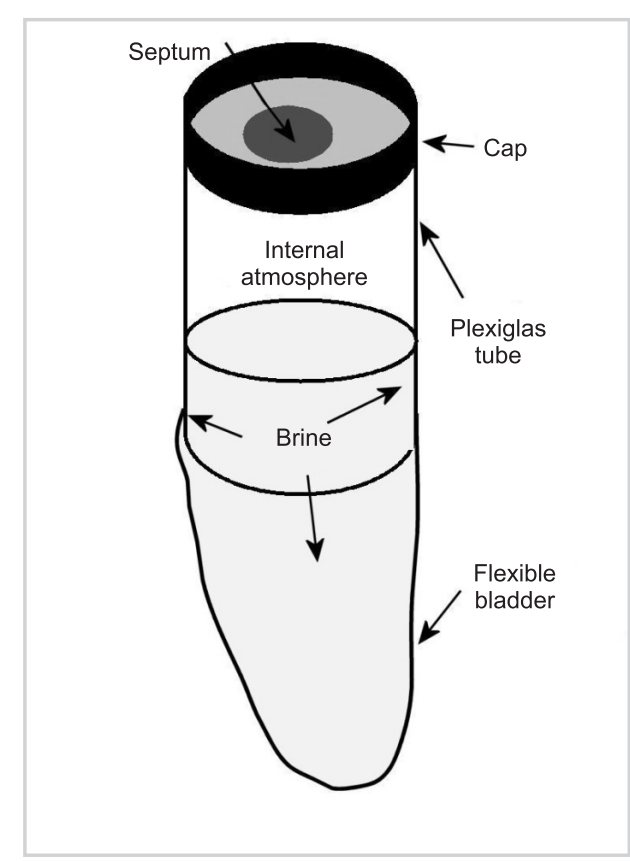

\section{Introduction}

As a living organism, fruit is a site of intense gas exchange due to respiration. Carbon dioxide, oxygen and ethylene are the main components involved in this biological activity. For several years, a lot of work has described the influence of these gases on maturity and ripening phenomena [1], concluding that gas plays an important role during storage and in physiological disorders.

In these studies, numerous methods were developed to regulate the respiratory rate of fruits, since it is directly linked to fruit's physiological development. Respiration can be controlled by temperature, trapping techniques or the use of controlled and modified atmospheres (obtained either by membranes, plastic bags or coatings). Classically, these phenomena are characterised by quantifying the gas exchange between the fruit and the external atmosphere. Such information is usually obtained by gas chromatography equipped with a hot wire detector (HWD).

One concern is to know if the use of these different techniques, which try to modify the close gaseous environment of the fruit, has an impact on the internal atmosphere of the fruit, or, in other words, if the gas balance is conserved between the internal and the external fruit atmosphere. An easy way of measuring the internal atmosphere of the fruit would help to appreciate these different phenomena better. Different methods have already been explored by measuring the ethylene content of whole fruit [2] or by direct micro-sampling with a gas syringe of selected pineapple fruit locules [3]. Both approaches were either very meticulous and needed great accuracy or had to use heavy equipment (e.g.,vacuum pump).The main difficulties lie in the quantity of gas released by the fruit, the sample representativeness and contamination from the surrounding air. In our paper, we present a technique to recover and measure the internal atmosphere of pineapple. We emphasise the sampling and quantification approaches and show that this procedure resolves former drawbacks in a very efficient way.

\section{Materials and methods}

\subsection{Plant material}

Experiments were performed with 30 pineapples each of Smooth Cayenne and Floran 41 (a CIRAD hybrid) varieties from Ivory Coast. The Floran 41 variety was at the M1 maturity stage and B9 grade. The Smooth Cayenne pineapple was at the commercial late stage.

\subsection{Materials}

Materials used to carry out the experiments were: a TSP gas chromatograph GC 8000 HWD equipped with a $250-\mu \mathrm{L}$ sample loop at a carrier gas flow of $6 \mathrm{~mL}$ helium $\cdot \mathrm{min}^{-1}$, a detector used at $120^{\circ} \mathrm{C}$, with wires used at $220^{\circ} \mathrm{C}$, an oven at $40{ }^{\circ} \mathrm{C}$ (isotherm), GSQ columns $[30 \mathrm{~m}$ with internal diameter of $0.53 \mathrm{~mm}$ (J\&W Scientific, Folsum CA) and Hp-Molsiv (30 $\mathrm{m}$ with internal diameter of $0.53 \mathrm{~mm}$ and thickness of $25 \mu \mathrm{m}$ (J\&W Scientific, Folsum CA)], a PET freezer bag of $30 \mathrm{~cm} \times 40 \mathrm{~cm} \mathrm{NF}$, a 100-mL Luer tip hypodermic syringe, gloves, a knife, and a receiving flask with bladder and septum (figure 1). 


\subsection{Chemicals}

The dipping solution used was $5 \mathrm{M}$ calcium chloride Caso HT (Solvay). The gas standards Abysse used had the following characteristics: ref. $\mathrm{G} 055$ at 30\% $\mathrm{CO}_{2}$, ref. G053 at $5 \% \mathrm{O}_{2}+5 \% \mathrm{CO}_{2}$ and ref. $\mathrm{G} 056$ at $0.5 \% \mathrm{CO}_{2}$.

\subsection{General principle}

\subsubsection{Procedure validation with standard gas}

The gas standard was released by bubbling it into the air-tight bag submerged in the saturated brine. The gas pocket was then transferred to an air-tight flask set up with a septum and a bladder. The headspace was sampled with a gas syringe and injected into the gas chromatograph.

\subsubsection{Procedure with pineapple}

The fruit's internal atmosphere was released after scratching the fruit into a calcium chloride-saturated brine. The recovered gas was transferred into an air-tight flask set up with a septum and a bladder. The headspace was sampled with a gas chromatograph or an IR analyser, at atmospheric pressure for easy use.

\subsection{Operating mode}

All the procedures were done in the brine solution. The time required for the procedure is less than $10 \mathrm{~min}$. Appropriate safety measures are needed (e.g., gloves).

\subsubsection{Release of the internal atmosphere}

The pineapple was soaked without the crown in the brine (using a saturated brine minimises both carbon dioxide and oxygen absorption in the water).

The fruit was shaken and rotated to eliminate all the air bubbles present on the pericarp (the error induced by ambient air contamination is thus reduced). The carbon dioxide is especially important because its solubility in water is about 24 times greater than oxygen at $100 \mathrm{kPa}$ and $15^{\circ} \mathrm{C}$. Manip-

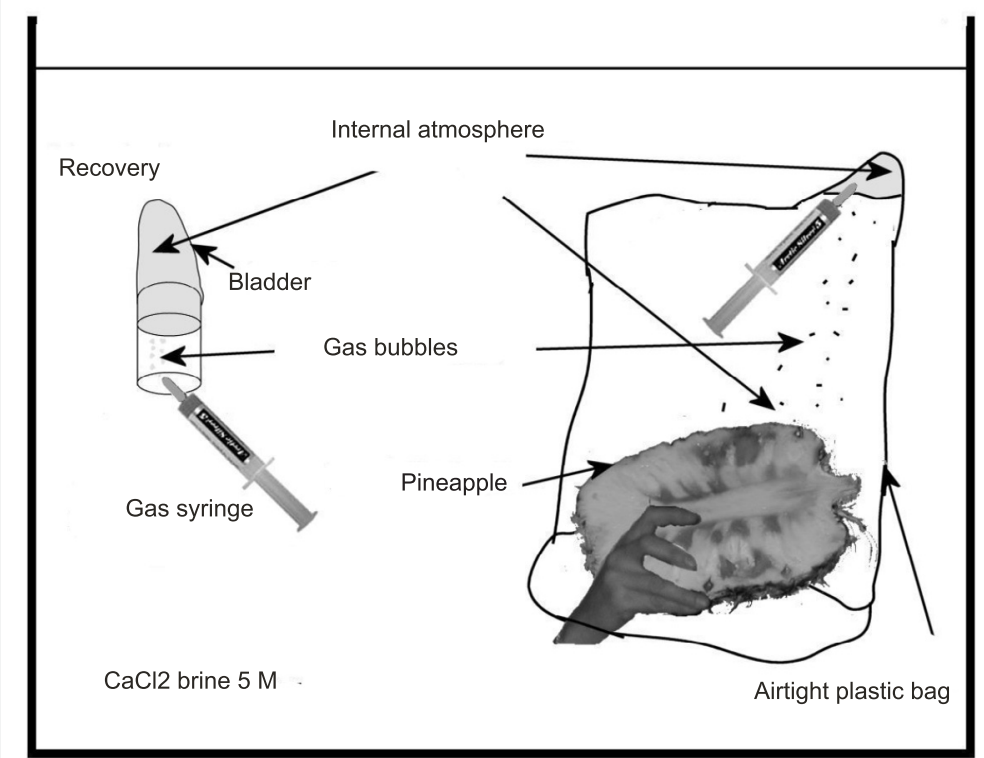

ulation under pure water would generate about a 30\% loss of gas, because of absorption phenomena.

The pineapple was longitudinally cut into two pieces, allowing a check of the internal physiology, and transferred to the air-tight bag.

The mesocarp was manually rubbed and pressed to release the internal atmosphere, which was collected at the top of the bag (the PET bag was initially purged of air) (figure 2).

\subsubsection{Transfer of the internal atmosphere}

The released atmosphere was removed with a gas syringe from the plastic bag [recovery of pineapple internal gas varied between (10 and 30) $\mathrm{mL}$.

The sample flask, with the bladder, was partially filled up backwards with the gas syringe (figure 2).

The flask was sealed with a cap equipped with a septum (figure 1).

The gas mixture was sampled with a gas syringe and injected into a sample loop to
Figure 2.

Setup used to study the pineapple internal mesocarp is manually rubbed and pressed to release the internal atmosphere, which is collected at the top of the bag, initially purged of air. atmosphere: the fruit 
Table I.

Measurements of the reproducibility of a sampling procedure tested for measuring internal atmosphere for pineapple.

Standard gas used Coefficient of variation for $\mathrm{CO}_{2}$ Coefficient of variation for $\mathrm{O}_{2}$

$\begin{array}{llc} & (\%) & (\%) \\ 30 \% \mathrm{CO}_{2} & 0.3 & - \\ 5 \% \mathrm{O}_{2}+5 \% \mathrm{CO}_{2} & 0.9 & 0.4 \\ 0.5 \% \mathrm{CO}_{2} & 1.2 & -\end{array}$

Table II.

Variability of pineapple internal $\mathrm{O}_{2}$ and $\mathrm{CO}_{2}$ contents measured in Smooth Cayenne and hybrid Floran 41 fruits using the method presented.

\begin{tabular}{lcccccc}
$\begin{array}{l}\text { Fruit } \\
\text { analysed }\end{array}$ & \multicolumn{2}{c}{$\begin{array}{c}\text { Mean } \\
(\%)\end{array}$} & $\begin{array}{c}\text { Standard deviation } \\
(\%)\end{array}$ & $\begin{array}{c}\text { Coefficient of variation } \\
(\%)\end{array}$ \\
& $\mathrm{O}_{2}$ & $\mathrm{CO}_{2}$ & $\mathrm{O}_{2}$ & $\mathrm{CO}_{2}$ & $\mathrm{O}_{2}$ & $\mathrm{CO}_{2}$ \\
\hline Smooth Cayenne & 15.4 & 18.6 & 1.7 & 2.8 & 10.9 & 14.9 \\
Floran 41 & 17.2 & 16.2 & 0.4 & 1.2 & 2.3 & 7.2
\end{tabular}

quantify both $\mathrm{O}_{2}$ and $\mathrm{CO}_{2}$. The transfer flask was set up with a flexible bladder. The headspace was then sampled without any external air contamination by automatically equilibrating the internal pressure at atmospheric pressure.

\section{Results}

Twenty complete procedure cycles were done with gas standards (G055, G053 and G056) to test the reproducibility of the technique (table I)

A coefficient of variation of about $5 \%$ is commonly regarded as a good result in gas chromatography. Coefficients of variation of between ( 0.3 and 1.2$) \%$, depending on the gas concentration, indicate good reproducibility. The increase in variability for low concentrations is explained by the proximity of the detection threshold. The higher variability for $\mathrm{CO}_{2}$ at the same concentration range as $\mathrm{O}_{2}$ results from their different sol- ubility coefficient [solubility $_{(\mathrm{CO} 2)}=0.592$, solubility $\left._{(\mathrm{O} 2)}=0.024\right]$.

Each pineapple of each variety was sampled once according to the procedure. All of the results were situated in the best standardisation range for reproducibility, of between ( 5 and 30)\% (table II). Obviously, the Smooth Cayenne variety at a commercial grade showed a wider variability compared with the pineapple hybrid Floran 41, where the origin and maturity were carefully controlled.

\section{Conclusions}

The main advantages of the method are that:

- it is fast to set up,

- the procedure is easy,

- it is representative of the whole fruit,

- there is recovery of a significant quantity of released gas (improves GC sensitivity),

- the reproducibility is good.

Nevertheless, certain drawbacks can be noticed:

- the fruit is destroyed,

- the concentrate brine solution is aggressive to the hands and gloves need to be used,

- care is needed to avoid contamination from the external atmosphere.

\section{References}

[1] Beaudry R.M., Effect of $\mathrm{O}_{2}$ and $\mathrm{CO}_{2}$ partial pressure on selected phenomena affecting fruit and vegetable quality, Postharv. Biol. Technol. 15 (1999) 293-303.

[2] Soler A., Maturation et sénescence de l'ananas en Côte d'Ivoire, USTL, thèse, Montpellier, France, 1991, $262 \mathrm{p}$.

[3] Paull R.E., Rohrbach K.G., Juice characteristics and internal atmosphere of waxed "Smooth Cayenne" pineapple fruit, J. Am. Soc. Hortic. Sci. 107 (3) (1982) 448-452. 
Puesta a punto de una técnica de muestreo y medida de la atmósfera interna de la piña.

Resumen - Introducción. Al ser un organismo vivo, el fruto es el centro de intercambios gaseosos intensos debidos a la respiración. El gas carbónico, el oxígeno y el etileno son los principales componentes implicados en esta actividad biológica; influyen en la madurez del fruto y en los metabolismos de la maduración. A fin de facilitar los estudios sobre la maduración de la piña, este documento presenta una técnica sencilla que permite recuperar y dosificar la atmósfera interna de la piña. Material y métodos. Se realizaron experimentos en 30 piñas maduras (dos variedades). Tras validar el procedimiento mediante un gas patrón, se aplicó la técnica a medias piñas. Se liberó la atmósfera interna del fruto, tras raspado de un fruto cortado en dos, en una salmuera saturada de cloruro de calcio. El gas recuperado se llevó a un frasco hermético en el que se adaptaron una vejiga flexible y un septo. El dispositivo permitió la dosificación a la presión atmosférica, con un cromatógrafo de gases o un analizador de gases por infrarrojos. Resultados. Para verificar la reproducibilidad de la técnica, se hicieron veinte ciclos completos del procedimiento con tres mezclas gaseosas de referencia distintas. Cada piña fue muestreada una vez utilizando este procedimiento. Todos los resultados obtenidos se situaron en la gama de estandarización. Conclusión. Se presentaron las principales ventajas e inconvenientes de esta técnica.

Francia / pina / maduración / respiración / intercambio de gases / medicon / métodos

To access this journal online: www.edpsciences.org 